\title{
EFFECTIVE STRUCTURE OF A WOODEN RESIDENTIAL BUILDING IN THE FORM OF A GEODESIC DOME WITH A UNIVERSAL CONNECTOR
}

\author{
${ }^{1}$ Gilodo A.Y., Ph.D., Assistant Professor, \\ gil@ soborka.net, ORCID: 0000-0001-5387-5538 \\ ${ }^{1}$ Kovtun V.P., engineer, \\ paka@ukr.net, ORCID: 0000-0002-7454-9296 \\ ${ }^{1}$ Arsirii A.N., Ph.D., Assistant Professor, \\ arsiriy@ukr.net, ORCID: 0000-0003-3262-1488 \\ ${ }^{1}$ Angel A.A., student \\ angelartem1999@gmail.com, ORCID: 0000-0001-8865-0558 \\ ${ }^{1}$ Odessa State Academy of Civil Engineering and Architecture \\ 4, Didrichson street, Odessa, 65029, Ukraine
}

\begin{abstract}
Since the middle of the twentieth century, a new architectural solution has been spherical shells broken down into elements by geodesic lines - circles with radii equal to the radius of the sphere. A geodesic dome is a dome made of a spherical polyhedron with an optimally distributed arrangement of vertices and edges tending to a perfect sphere. Using the technical capabilities of computer design, digital models of the layout and calculation of geodesic domes became available. It is possible not only to calculate multi-mesh network layouts with high accuracy, but also to automate the design. At the same time, it cannot be said that the optimal system has already been obtained and studied. The issues of optimal shaping, taking into account a simple universal connector and confirmation of theoretical results by field tests, remain not fully studied. Development of the design of a mesh wooden house in the form of a geo dome with optimal parameters of the geodetic network and nodal connections of the frame elements using a universal connector is the theme of this publication. The proposed form of division is a fullerene polyhedron describing a sphere and consisting of five and hexagonal faces. The dome polyhedron is built on the basis of the icosahedron. The number of partitions of vertices and edges that make up the split edge - the frequency, is chosen equal to 3. The first class of partitioning by the "equal chords" method is adopted. The proposed universal connector for connecting parts of building structures at any angle and a method of mounting building structures using a universal connector. As a result of introduction of new technical decisions we receive essential simplification of a design, reduction of quantity of its components, at the same time increase of its manufacturability and providing an opportunity to connect details of building designs in an end face at any angle.
\end{abstract}

Keywords: wooden geodesic dome, spherical house, universal connector, nail connections.

Introduction. A hundred years ago, domes were assembled from elements designed by meridional-ring division of spherical surfaces. A significant disadvantage of using such a laying is the large number of types of constituent elements. Since the middle of the twentieth century, a new architectural solution has been spherical shells laying out into elements by geodesic lines - circles with radii equal to the radius of the sphere. This made it possible to construct staggered networks with significantly fewer types and sizes of building elements. A geodesic dome is a dome made of a spherical polyhedron with an optimally distributed arrangement of vertices and edges tending to a perfect sphere. It is usually built on the basis of an icosahedron (20 triangular faces) or a dodecahedron (12 pentagonal faces).

The principle of constructing a domed frame was first patented by Richard Fuller. Fuller's biosphere design is interesting because in this way it is possible to achieve a large volume of internal space with a low weight of the building. The system of interconnected rods has a high 


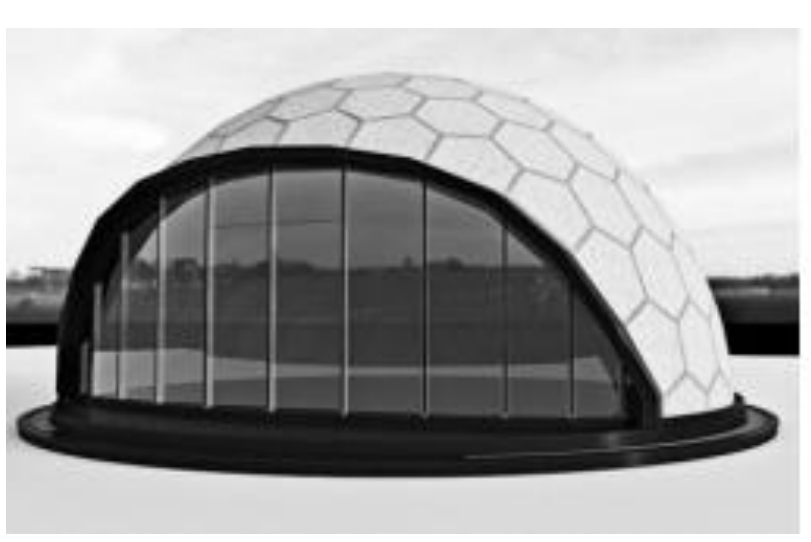

Fig. 1. Geodome

bearing capacity regardless of the strength characteristics of the material. The higher the height of the dome, the more elements are used, formed by triangles and polygons. The increase in the number of geometric shapes in the dome increases the bearing capacity of the structure.

One of the main advantages of a spherical house is its shape (Fig. 1). These buildings have the best ratio of external wall area to internal space. Due to the smaller area, the efficiency of energy consumption for heating and air conditioning of the room increases. The spherical house has excellent stability. This shape has a high bearing capacity. The weight is distributed perfectly evenly, which allows it to withstand heavy loads and economize on ground work. Remarkable aerodynamic properties - the "streamlined" shape of the geo-dome increases resistance to even the most powerful air currents. The sphere has excellent physical properties - air circulation inside occurs in such a way that there is practically no heat loss. The stability of the spherical frame to shocks and tremors allows us to recommend this type of construction for the most earthquake-prone areas. You can change the number of entrances to the building, as well as windows, and this in no way affects its strength. The design is modular, does not require heavy construction equipment for installation; during construction, much less building materials and time are used than when erecting an ordinary rectangular building. Spherical houses are economical, while they do not lose quality. Residential building in the form of a geo-dome made of wood is environmentally friendly, which has a positive effect on the health of its owners.

This constructive form also has disadvantages that prevent its widespread use. In mesh domes, the load-bearing elements of the frame adjoin each other at different angles, but a universal reliable design solution for the assembly has not yet been found. The varieties of joints that exist today can be conditionally divided into several main groups according to the nature of the work: for chipping/ bearing (cogging, loose tongues, notch gauges); bending (dowel pins, lag screws, bolts, wood screws, staples, screws, nails); shearing (adhesive joints and joints on adhesive washers); straining (steel clamps, bolts, straps, staples, pads). However, they all have disadvantages and do not fully meet modern requirements.

The development of the structure of a mesh wooden dome with optimal parameters of the geodetic grid and nodal connections of the frame elements using a universal connector is the topic of this publication.

Analysis of the latest achievements and publications. The fundamentals for the design and construction of geodesic domes were developed by the American inventor R.B. Fuller [1]. The first dome with a diameter of $18 \mathrm{~m}$ was built by him in 1952 in the state of Masachusetts. Fuller developed complex nodes for connecting elements that allow changing the angle of their inclination in two planes. A large number of domes were set, mostly made of metal. The basic theoretical and practical work on the staking of domes into elements and the installation of structures should include the studies of M.S. Tupolev [2]. He built his first dome of triangular wooden panels in 1949. A truncated icosahedron was taken as a basis, consisting of twelve regular pentagons and twenty regular hexagons. Embrace of this design reappeared in the second decade of the twenty-first century. Using the technical capabilities of computer design, Pavlov G.M., Lakhov A.Y., Antoshkin V.D. [3-5] proposed digital models for staking and calculating geodesic domes. It became possible not only to calculate multimesh network layouts with high accuracy, but also to automate the design. Using the offered software products in the ArchiCAD system, together with specially designed library elements, various partitioning systems can be obtained. At the same time, it cannot be said that the optimal system has already been obtained and studied. The issues of optimal shaping, taking into account a simple universal connector and confirmation of theoretical results by full level tests, remain not fully studied. 
To connect the elements working in compression, frontal notches or frontal stops are used, the ends of the elements are cut out at certain angles. On the stops, pads are additionally installed, connected with bolts or nails, to ensure stable operation of the connection. When connecting stretched elements, at joints, when connecting elements at an angle, it becomes necessary to use mechanical bonds. The development and implementation of new types of joints for wooden structures mainly follows the path of using various dowels. Noteworthy are the hardened steel threaded nails used in the USA and Germany, which determine their high bearing capacity when working in shear and pull-out. Reinforcement of the pin connection with additional elements reduces the likelihood of wood chipping and bearing [6]. Interesting results of testing the dowel joints of large-span wooden structures reinforced with steel plates inserted into pre-cut grooves are presented in the work [7]. When using nail connections, as well as when using pins inserted into pre-drilled holes, all connections are simultaneously put into use. The pliability of the bonds in elements with such joints is due to the bearing of the wood in the gainers, as well as the bending deformations of the pins themselves. From the existing nomenclature of nodal joints, the modern requirements for increased strength and low deformability are met by joints on adhesives, dowels and dowel plates, ring dowels and washers, as well as glued-in steel pins. However, all these types of connections cannot be called universal and do not fully meet all the requirements for modern industrial wooden supporting structures. In addition to strength and rigidity, important factors when choosing one or another type of joints on a wooden frame are manufacturability, movability and cost-effectiveness.

The purpose of the study is to develop a new design of a prefabricated mesh dome made of glued wood with a universal connector, to carry out experimental and theoretical studies of the operation of the dome, to determine its bearing capacity under the influence of a static load, to offer recommendations for calculation and design.

It is necessary to select the optimal layout of the dome surface from a large number of options. At the same time, it is necessary to take into account the functional purpose of the structure - a residential building, as well as the mandatory requirements for ensuring strength, rigidity, spatial stability, in conjunction with the possibility of implementing a modern architectural and planning solution, economic efficiency, energy saving and ventilation.

First, let us determine the frequency of splitting the face of the original polyhedron of the dome when approximating to the sphere, then the fraction of the sphere forming the dome. Considering that a dome with connectors connections is being designed, it should be remembered that an increase in the frequency of splitting increases the rigidity of the structure, but also increases the number of vertices nodes, that is, connectors and, as a consequence, leads to an increasing cost of the structure. In addition, the number of items is increasing, and, accordingly, the number of complex cuts of the dome elements at different angles. The second task is to select a material, based on its physical and mechanical properties. We will analyze the elements made of glued wood, which are composed of OSB panels and wooden beams, and high-strength expensive LVL beams glued from veneer using an innovative technology, which allows obtaining a material superior in its properties to solid wood. At the same time, we will determine the possibility of joint work of each type of wood with a steel universal connector. A preliminary analysis of the existing types of fittings showed that the best results are given by keyed and dowel joints. The challenge is to offer a design that combines their merits without increasing the cost and complexity of manufacturing and assembly.

Research methodology. When calculating structures, they usually operate with idealized design schemes, in which the connections of structural elements are accepted either absolutely rigid or hinged. Joints in wood structures are resilient. The real characteristics of the deformability of nodes in the calculation of spatially regular structures were studied in works $[9,10]$. The numerical values of the stiffness coefficients in each specific case are set individually and will depend on the design of the node and the type of applied joints. In the general case, they will range from an ideal hinge to an absolutely rigid connection, and taking them into account is very important for statically indeterminate systems, such as domes. To determine the stiffness of ties, one should use the characteristics of the deformability of joints of wooden structures, which can be found empirically or taken from the DBN

Bulletin of Odessa State Academy of Civil Engineering and Architecture, 2021, no. 82, page 19-26 
standards. It is most expedient to apply the finite element method in the form of a displacement method, which allows the determination of forces and is available for engineering calculations. It is convenient to represent the design scheme of a structure with ties restrained by elastic members as a rod model with rigid nodes, to which the rods adjoin through elastic hinges.

The first stage of the experimental study will be to study the degree of deformability of the full-scale fragments of the dome. Then the work of the frame laminated wood dome on its model. The main task is to study the stress-strain state of the prototype under load. For which there will be recorded vertical displacements and deformations of compliance in the nodes. Simultaneously, the determination of the edge deformations in the rods, which are used to determine the stresses. Experimental data will be compared with the results of theoretical determination of forces and deformations.

Research results. The dome polyhedron is built on the basis of the icosahedron. The number of partitions of vertices and edges that make up the split edge - frequency, is chosen equal to 3 (Fig. 2). The first class of partitioning by the method of "equal chords" is adopted - we divide the large triangle of the icosahedron into small triangles by dividing each side of the large triplet into three parts, then

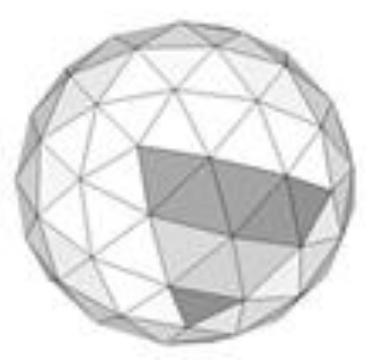

Fig. 2. Frequency $3 \mathrm{~V}$ connect the points on the edges to each other and obtain a flat grid of 9 triangular, which we then project onto the sphere. The calculation of the dome is performed according to a given radius $\mathrm{R}$. The length of three types of identical edges for a dome with a frequency of $3 \mathrm{~V}$ is equal to: $A=0,34863 R, B=0,40355 R, C=0,41241 R$, the shape of the partition is a fullerene polyhedron describing a sphere and consisting of five and hexagonal faces. The base area $S=\pi R^{2}$, the surface area $S=4 \pi R^{2}$, the surface area of the sphere depends on its height $H$ : $\mathrm{S}=2 \pi \mathrm{RH}$.

The results of calculating the geometric parameters obtained by the dome calculator are as follows. For a geodesic dome 7/12 part of a sphere, with a diameter of 12 meters from elements with a cross section of $300 \times 50 \mathrm{~mm}$ : height from the base $-8,32 \mathrm{~m}$, base area $109,66 \mathrm{~m}^{2}$, types of faces 3-56 pieces, types of edges - 4-185 pieces, types of tops - 2-130 pieces. The total length of the ribs is $265 \mathrm{~m}$, the volume of the ribs is $3,9 \mathrm{~m}^{3}$, the maximum rib length is $1554 \mathrm{~mm}$, the angle of sawing of adjacent edges is $156,1-159,92^{\circ}$. The designation of the edges, faces and vertices is shown on the diagram of the dome frame, on the plan there is the projection of the dome vertices onto the plane passing through the base of the dome (Fig. 3).
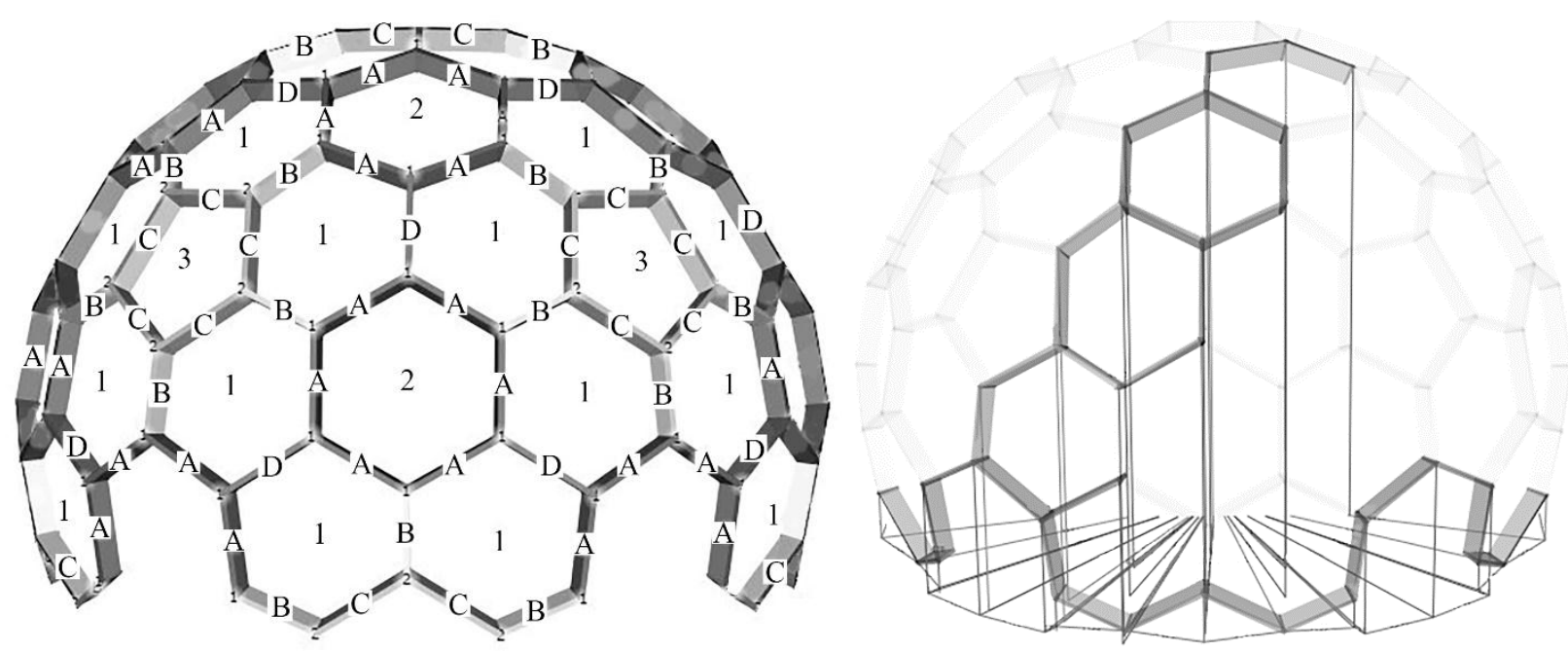

Fig. 3. Geodome frame 
The proposed universal connector [8] for connecting parts of building structures at any angle (Fig.4, Fig. 5), includes swivel fasteners 1 and a connecting fastener 2, which are installed in the connected parts 3 , fastener 4 is a tightening bolt, and nut 5 , which is part of the connecting fastener 2 , and is designed to tighten the fastener 4 . Each of the swivel fasteners 1 consists of a swivel part 6 , which has a hole 7 and is rigidly connected to the end of the rod with a threaded end 8 with the location of the central longitudinal axis hole 7 perpendicular to the central longitudinal axis of the rod with a threaded end 8 . A rod with a threaded end 8 made with the possibility of making a threaded connection through a hole 9 in the side surface of a ring 10 with a nut 11 for fixing a rod with a threaded end, while the central longitudinal axis of the swivel part 6 is perpendicular to the central longitudinal axis of the rod with a threaded end 8 , and the central longitudinal the axis of the hole 9 in the side surface of the ring 10 is perpendicular to the central longitudinal axis of the central hole 12 of the ring 10. The holes 7 of the swivel parts 6 are made with the possibility of free rotation of each of the swivel fastening elements 1 around the rod of the fastening element 4 when it is placed in the indicated holes 7 . The nut 5 for tightening the tightening fastening element 4 is part of the structure of the connecting fastening element 2 and is rigidly connected to its sides with the end of the rod with the threaded end 13 with the location of the central longitudinal axis of the hole in the nut 5 for tightening the fastening element 4 perpendicular to the central longitudinal axis of the rod with the threaded end 13. The length of the rod of the fastening element 4 ensures the location of the rotary fasteners 1 on it and the possibility of making a threaded connection with the nut 5 for tightening the fastening element 4. A flat washer 18 is installed under the head of the fastening element 4.

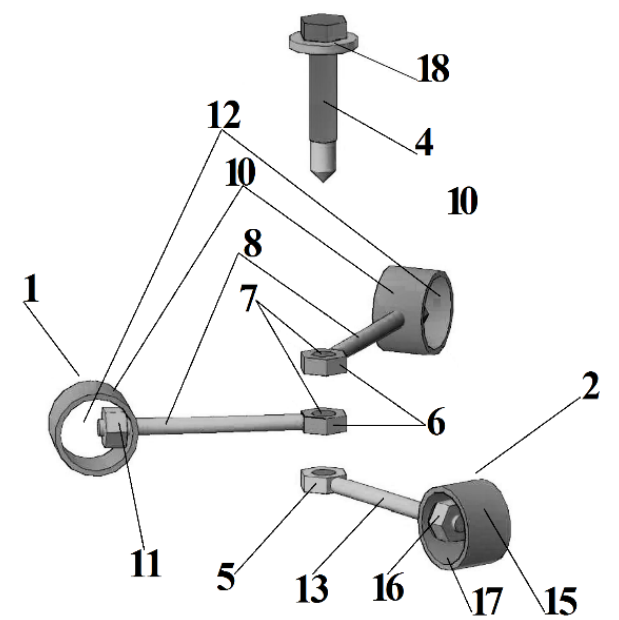

Fig. 4. Universal connector

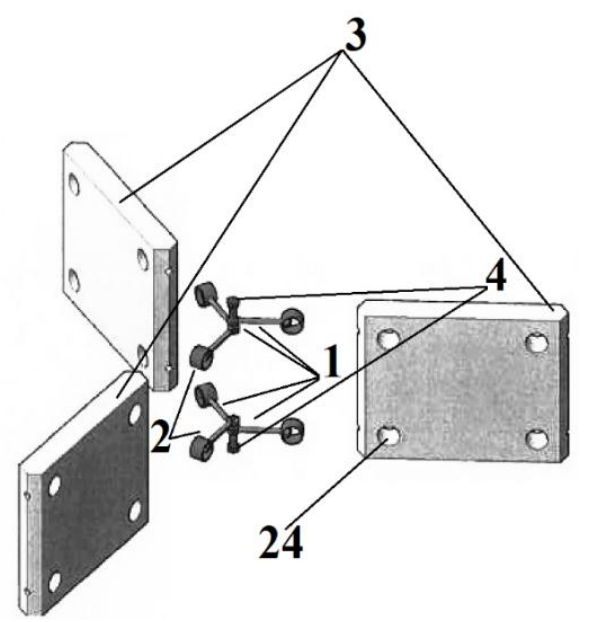

Fig. 5. Connecting three elements

The proposed method for mounting building structures using a universal connector is performed as follows. To mount a building structure by connecting two or more parts (Fig. 6) use one or more universal connectors. First, the parts to be joined 3 are prepared for installation: the ends of the parts to be joined 3 are milled at a certain angle. Then, at the ends of the parts to be connected, the recesses 19 are milled for the location of the tightening fastener 4 in them when the ends of the parts to be connected are aligned and the groove 20 for the location of the nut 5 and the swivel parts 6 in it when the ends of the parts are aligned, and holes 21 are drilled along the conductor for the location of the dowel 22 when aligning the ends of the parts. At the ends of the connected parts 3 , holes 23 are drilled to place rods with threaded ends 8 and a rod with a threaded end 13. On the lateral sides of the parts 3 to be connected, holes 24 are made to locate the rings 10 of the swivel fasteners 1 and the ring 15 of the connecting fastener 2. After that, installation of a building structure is performed (Fig. 7). 


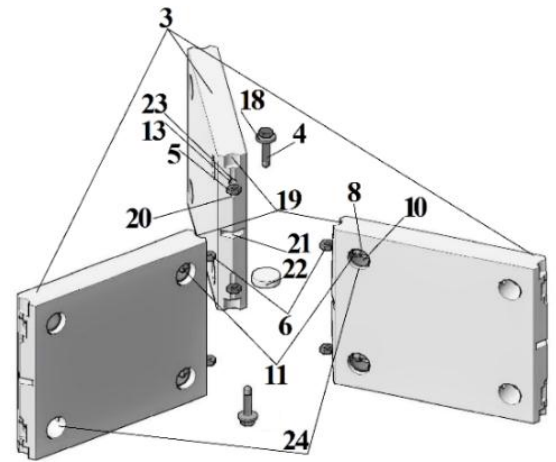

Fig. 6. Mounting assembly scheme

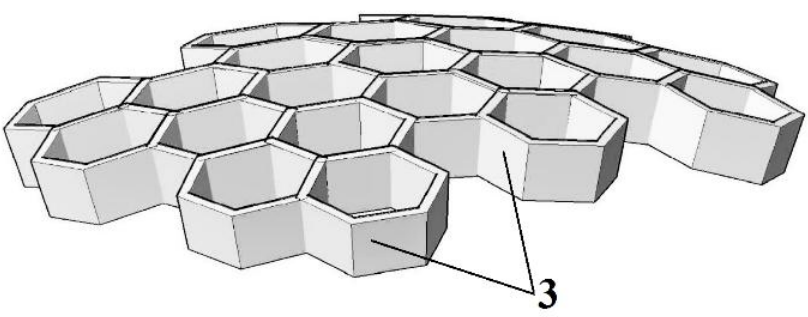

Fig. 7. Mounted fragment of the dome

\section{Conclusions and prospects for further research:}

1. A new design of a mesh built-up glued wood dome with a universal connector is proposed.

2. A universal connector has been developed for connecting parts of building structures at an arbitrary angle, which leads to the appearance of qualitatively new technical properties:

- a significant simplification of the design, a decrease in the number of its components simultaneously with an increase in manufacturability and a decrease in metal consumption;

- providing the ability to connect parts of building structures at the ends at an arbitrary angle;

- the ability to create building structures with any geometric parameters: rectangular, in the form of a "honeycomb", complex symmetrical and asymmetrical shapes, and others.

3. A method for assembling building structures using a universal connector is proposed.

4. In further research it is planned to:

4.1. Conduct a study of the stress-strain state of a mesh glued wood dome with a universal connector:

- determine the method of numerical experiment and build a computer model of the dome;

- calculate the bearing elements of the dome for the action of static loads, taking into account the elastic-plastic work of the nodal joints.

4.2. Carry out experimental studies of a mesh glued wood dome:

- to determine the physical and mechanical properties of the materials of the dome elements;

- to develop an experimental methodology with the design and implementation of an installation for testing full-scale fragments and a dome model;

- to test the operation of full-scale fragments and the dome model under static load.

4.3. Based on the research carried out, to design and build a cottage-type residential building in the form of a geo-dome made of glued wood with a universal connector.

\section{References}

[1] R.B. Fuller, "Geodesic dome", Perspecta, no. 1, pr. 30-33, 1952.

[2] M.S. Tupolev, Novye varianty sbornykh kupolov i svodov-obolochek. V kn.: Novye vidy prostranstvennych pokrytiy: Ychebnoe posobie, MArchI, pp. 4-37, 1963.

[3] G.N. Pavlov, A.N. Suprun, "Geodezicheskiye kupola - proyektirovaniye na sovremennom urovne", SAPR i grafika. M., pp. 25-27, 2006.

[4] A.YA. Lakhov, "Priblizhennyy sposob opredeleniya maksimal'nykh rastyagivayushchikh napryazheniy v sterzhnyakh dvukhkonturnykh geodezicheskikh kupolov sistemy «R» ot vozdeystviya sobstvennogo vesa", Vestnik MGSU, vol. 1, pp. 58-65, 2014.

[5] V.D. Antoshkin, Konstruktivno-tekhnologicheskiye resheniya sbornykh sfericheskikh obolochek: diss. d-ra tekhnicheskikh nauk: 05.23.01 Nacionalnyy mordovskiy gosydarstvennyy universitet. Saransk, 2017.

[6] N.J. Blass, P. Schädle, "Ductility aspects of reinforced and non-reinforced timber joints", Engineering Structures, vol. 33, pp. 3018-3026, 2011. 
[7] Milan Šmak, Bohumil Straka, "Development of new types of timber structures based on theoretical analysis and their real behaviour", Wood research, 59 (3), pp. 459-470, 2014.

[8] Patent na vinakhíd №117276. Uníversal'niy z'êdnuvach dlya z'êdnannya detaley budível'nikh konstruktsíy píd dovíl'nim kutom nikh konstruktsíy za dopomogoyu uníversal'nogo z'êdnuvacha. Kovtun V.P. opubl. 10.07.2018.

[9] V.A. Kononov, Raschet mnogonagel'nykh soyedineniy derevyannykh konstruktsiy s uchetom netochnosti ikh sborki i izgotovleniya elementov: avtoref. dis. kand. tekhn. nauk: 05.23.01 Leningradskij inzhenerno-budivel'nyy institut, Leningrad, 1988.

[10] N.B. Krasnopol'skaya, Raschet sterzhnevykh sistem s uprugo-podatlivymi uzlami na prochnost', ustoychivost' i kolebaniya: avtoref. diss. kand. tekhn. nauk: 05.23.01 Leningradskij politehnicheskij institut, Leningrad, 1973.

\title{
ЕФЕКТИВНА КОНСТРУКЦІЯ ДЕРЕВ'ЯНОГО ЖИТЛОВОГО БУДИНКУ У ВИГЛЯДІ ГЕОДЕЗИЧНОГО КУПОЛА 3 УНІВЕРСАЛЬНИМ КОНЕКТОРОМ
}

\author{
${ }^{1}$ Гілодо О.Ю., к.т.н., доцент, \\ gil@ soborka.net, ORCID: 0000-0001-5387-5538 \\ ${ }^{1}$ Ковтун В.П., інженер, \\ paka@ukr.net, ORCID: 0000-0002-7454-9296 \\ ${ }^{1}$ Арсірій А.М., к.т.н., доцент, \\ arsiriy@ukr.net, ORCID: 0000-0003-3262-1488 \\ ${ }^{1}$ Ангел А.О., студент, \\ angelartem1999@gmail.com, ORCID: 0000-0001-8865-0558 \\ ${ }^{1}$ Одеська державна академія будівництва та архітектури \\ вул. Дідріхсона, 4, м. Одеса, 65029, Україна
}

\begin{abstract}
Анотація. Новим архітектурним рішенням з середини двадцятого століття стали сферичні оболонки 3 розбивкою на елементи геодезичними лініями - колами 3 радіусами, рівними радіусу сфери. Геодезичний купол - це купол із сферичного багатогранника 3 оптимально розподіленим розташуванням вершин i граней, які прагнуть до ідеальної сфери. Використовуючи технічні можливості комп'ютерного проектування, стали доступними цифрові моделі розбивки і розрахунку геодезичних куполів. Можливо не тільки з високою точністю розраховувати багатокоміркові мережні розбивки, але й автоматизувати проектування. У той же час не можна сказати, що оптимальна система вже отримана i досліджена. Не повністю вивченими залишаються питання оптимального формоутворення 3 урахуванням простого універсального конектора і підтвердження теоретичних результатів натурними випробуваннями. Розробка конструкції сітчастого дерев'яного будинку у вигляді геокупола з оптимальними параметрами геодезичної сітки і вузловими з'єднаннями елементів каркаса за допомогою універсального конектора тема цієї публікації. Запропонована форма розбивки - багатогранник фулерен, що описує сферу і складається 3 п'яти і шестикутних граней. Багатогранник купола будується на основі ікосаедра. Кількість розбиття вершин і ребер, що складають розбите ребро - частота, обрана рівною 3. Прийнято перший клас розбиття методом «рівних хорд». Запропонований універсальний з'єднувач для з'єднання деталей будівельних конструкцій під довільним кутом і спосіб монтажу будівельних конструкцій за допомогою універсального з'єднувача. В результаті впровадження нових технічних рішень отримуємо суттєве спрощення конструкції, зменшення кількості складових одночасно 3 підвищенням iї технологічності та забезпечення можливості з'єднувати деталі будівельних конструкцій у торці під довільнім кутом.
\end{abstract}

Ключові слова: дерев'яний геодезичний купол, сферичний будинок, універсальний конектор, нагельне з’єднання. 


\title{
ЭФФЕКТИВНАЯ КОНСТРУКЦИЯ ДЕРЕВЯННОГО ЖИЛОГО ДОМА В ВИДЕ ГЕОДЕЗИЧЕСКОГО КУПОЛА С УНИВЕРСАЛЬНЫМ КОННЕКТОРОМ
}

\author{
${ }^{1}$ Гилодо А.Ю., к.Т.Н., доцент, \\ gil@ soborka.net, ORCID: 0000-0001-5387-5538 \\ ${ }^{1}$ Ковтун В.П., инженер, \\ paka@ukr.net, ORCID: 0000-0002-7454-9296 \\ ${ }^{1}$ Арсирий А.Н., к.т.Н., доцент, \\ arsiriy@ukr.net, ORCID: 0000-0003-3262-1488 \\ ${ }^{1}$ Ангел А.О., студент, \\ angelartem1999@gmail.com, ORCID: 0000-0001-8865-0558 \\ ${ }^{1}$ Одесская государственная академия строительства и архитектуры \\ ул. Дидрихсона, 4, г. Одесса, 65029, Украина
}

\begin{abstract}
Аннотация. Новым архитектурным решением с середины двадцатого века стали сферические оболочки с разбивкой на элементы геодезическими линиями - окружностями с радиусами, равными радиусу сферы. Геодезический купол - это купол из сферического многогранника с оптимально распределенным расположением вершин и граней, стремящихся к идеальной сфере. Используя технические возможности компьютерного проектирования, стали доступными цифровые модели разбивки и расчёта геодезических куполов. Возможно не только с высокой точностью рассчитывать многоячеистые сетевые разбивки, но и автоматизировать проектирование. В то же время нельзя сказать, что оптимальная система уже получена и исследована. Не полностью изученными остаются вопросы оптимального формообразования с учётом простого универсального коннектора и подтверждения теоретических результатов натурными испытаниями. Разработка конструкции сетчатого деревянного дома в виде геокупола с оптимальными параметрами геодезической сети и узловыми соединениями элементов каркаса с помощью универсального коннектора тема данной публикации. Предлагаемая форма разбивки - многогранник фуллерен, описывающий сферу и состоящий из пяти и шестиугольных граней. Многогранник купола строится на основе икосаэдра. Количество разбиений вершин и рёбер, составляющих разбитое ребро - частота, выбрана равной 3. Принят первый класс разбиения методом «равных хорд». Предложен универсальный конектор для соединения деталей строительных конструкций под произвольным углом и способ монтажа строительных конструкций с помощью универсального коннектора. В результате внедрения новых технических решений получаем существенное упрощение конструкции, уменьшение количества составляющих, одновременно с повышением ее технологичности и обеспечения возможности соединять детали строительных конструкций в торце под произвольным углом.

Ключевые слова: деревянный геодезический купол, сферический дом, универсальный коннектор, нагельные соединения.
\end{abstract}

Стаття надійшла до редакції 9.12.2020 